\title{
EFEKTIVITAS PENDIDIKAN KESEHATAN TERHADAP KECERDASAN EMOSIONAL SISWA DI SMK N 5 PADANG
}

\author{
Amelia Susanti ${ }^{1}$, Nita Herlinda ${ }^{2}$ \\ ${ }^{1}$ Keperawatan, STIKes Alifah Padang, Padang, Sumatera Barat \\ Email: ameliaaska@gmail.com \\ ${ }^{2}$ Keperawatan, STIKes Alifah Padang, Padang, Sumatera Barat \\ Email: nitaherlinda23@gmail.com
}

\begin{abstract}
ABSTRAK
Upaya mengembangkan emosi remaja agar berkembang ke arah kecerdasan emosional dapat dilakukan dengan memberikan pemahaman tentang kecerdasan emosional yang baik pada remaja melalui pendidikan kesehatan, layanan konseling serta pelatihan emosi. Penelitian ini bertujuan untuk mengetahui pengaruh pendidikan kesehatan terhadap kecerdasan emosional siswa di SMK N 5 Padang. Jenis penelitian ini adalah kuantitatif dengan desain quasy experiement one group pretest-posttest dengan kelompok kontrol yang dilaksanakan di SMK N 5 Padang. Pengambilan data dari tanggal 1-10 Maret 2018 dengan jumlah sampel 42 siswa menggunakan kuesioner. Hasil penelitian menyatakan rerata kecerdasan emosional pada kelompok kontrol pretest 144,48 dan post test 142,95. Hal ini menunjukkan tidak ada perbedaan yang signifikan antara pre test dan post test pada kelompok kontrol. Pada kelompok intervensi pretest 145,38 dan posttest 151,38. Hal ini menunjukkan ada perbedaan yang signifikan antara pre test dan post test pada kelompok intervensi.Hasil uji statistik didapatkan ada perbedaan yang signifikan rerata kecerdasan emosional setelah diberikan intervensi pendidikan kesehatan Diharapkan sekolah khususnya bagian kesiswaan SMK N 5 Padang agar dapat menjadikan kegiatan pendidikan kesehatan tentang kecerdasan emosional siswa ini ke dalam bagian kegiatan UKS SMK N 5 Padang.
\end{abstract}

\section{Kata kunci: Pendidikan Kesehatan, Kecerdasan Emosional, Remaja}

\begin{abstract}
Efforts to develop teenage emotions to develop in the direction of emotional intelligence can be done by providing an understanding of good emotional intelligence in adolescents through health education, counseling services and emotional training. This study aims to determine the effect of health education on the emotional intelligence of students in SMK $N 5$ Padang. This research type is quantitative with ques experiement one group pretest-posttest design with control group conducted in SMK N 5 Padang. Retrieval of data from March 1-10, 2018 with a sample size of 42 students using questionnaires. It is expected that the school especially part of Student SMK N 5 Padang in order to make health education activities about students' emotional intelligence into the student activities.
\end{abstract}

Keywords : Health Education, Emotional Intelligence, Adolescence 


\section{PENDAHULUAN}

Masa remaja merupakan masa usia antara 13 dan 20 tahun. Masa remaja ini terdiri dari tiga subfase yaitu: remaja awal (11 sampai 14 tahun), remaja pertengahan (15 sampai 17 tahun) dan remaja akhir (18 sampai 20 tahun) (Perry \& Potter, 2009). Di wilayah Asia Tenggara jumlah remaja tahun 2015 hampir seperempat atau $18,8 \%$ (362,2 juta individu) dari total penduduk. Dari jumlah tersebut, usia 13-17 tahun terdiri dari 181 orang juta atau hampir sepersepuluh $(9,4 \%)$ dari total populasi. Di tahun-tahun mendatang, kelompok ini mungkin akan mendapatkan bagian yang lebih besar dari jumlah keseluruhan (WHO, 2017). Hasil survei penduduk tahun 2015 menunjukkan bahwa penduduk usia 15-24 tahun mencapai $42.061,2$ juta atau sebesar 16,5 persen dari total penduduk Indonesia (Lembaga Demografi FEB UI, 2017). Berdasarkan hasil proyeksi penduduk Indonesia 2010-2035, tahun 2016 jumlah penduduk remaja di Indonesia diproyeksikan mencapai 66,3 juta jiwa atau sekitar 25,6 persen dari total jumlah penduduk Indonesia (BKKN, 2016).

Masa remaja merupakan periode transisi perkembangan yang terjadi antara masa kanak-kanak dan masa dewasa, yang melibatkan perubahan-perubahan baik itu secara biologis, kognitif dan sosioemosional (Santrock, 2007). Transisi perkembangan ini juga nampak jelas, salah satunya dalam perkembangan sosioemosional remaja. Seperti yang dikemukakan oleh Mappiare (2008) yang mengatakan sebagian besar remaja mengalami ketidakstabilan dari waktu ke waktu sebagai konsekuensi dari usaha penyesuaian diri pada pola perilaku dan harapan sosial yang baru namun meskipun emosi remaja seringkali sangat kuat dan tidak terkendali tetapi pada umumnya dari tahun ke tahun terjadi perbaikan perilaku emosional.

Survei yang dilakukan oleh Pusat Penelitian Kesehatan Universitas Indonesia bersama Badan Narkotika Nasional (BNN) menemukan pada tahun 2016 kelompok pemakai narkoba yaitu pelajar SMA sebesar 2,4 \% (Lembaga Demografi FEB UI, 2017). Menurut laporan Polda Metro Jaya untuk kasus kenakalan remaja seperti tawuran juga mengalami peningkatan dari 1 kasus di tahun 2015 menjadi 5 kasus di tahun 2016. Penyebaran HIV/AIDS juga merambat hingga pelajar. Data Komisi Penanggulangan AIDS (KPA) Nasional mengatakan ada 6 pelajar yang mengidap HIV tahun 2016 (Santoso, 2017). Data Komisi Perlindungan Anak Indonesia berdasarkan klaster perlindungan anak menyebutkan beberapa kasus yang mengalami peningkatan ditahun
2016 diantaranya anak pengguna napza dari 74 kasus pada tahun 2015 menjadi 88 kasus tahun 2016, anak pelaku kekerasan di sekolah (bulliying) dari 93 kasus tahun 2015 menjadi 112 kasus tahun 2016, anak sebagai pelaku aborsi dari 19 kasus tahun 2015 menjadi 33 kasus tahun 2016.

Masalah kenakalan remaja dan kasus narkoba sangat tinggi di Sumatera Barat, hasil penelitian Universitas Indonesia dan BNN tahun 2016, Sumatera Barat menempati urutan ke 3 tertinggi penyalahgunaan narkoba. Pada kelompok pelajar dan mahasiswa mencapai 20.906 orang (Puslitdatin BNN, 2017). Selain itu banyak sekali problem remaja yang belum tertangani dengan baik oleh pihak sekolah khususnya masalah tawuran antar pelajar. Berdasarkan data Satuan Polisi Pamong Praja (Satpol PP) Kota Padang tahun 2015 dari 433 kasus, 220 kasus diantaranya tawuran didominasi oleh pelajar yang berasal dari Sekolah Menengah Kejuruan (SMK) kemudian diikuti oleh pelajar Sekolah Menengah Pertama (SMP) sebanyak 90 orang dan anakanak yang bukan pelajar sebanyak 123 orang. Pada bulan Agustus sampai dengan Oktober tahun 2016 Satuan Polisi Pamong Praja Kota Padang telah menertibkan sebanyak 163 orang pelajar yang berkeliaran pada saat jam pelajaran.

Sepanjang tahun 2017, tawuran antar pelajar tidak lagi menggunakan tangan kosong, mereka bahkan menggunakan batu sebagai alat menyerang/mempertahankan diri tetapi telah menggunakan senjata tajam, seperti gir, pisau, samurai dll. Pada harian redaksi Sumbar bulan Januari 2017, tercatat tiga orang siswa tertangkap tangan tengah melakukan tawuran menggunakan senjata tajam sabit dan pedang. Bulan Agustus 2017, Polresta Padang menangkap 20 remaja yang pada umumnya pelajar SLTA dan SMP bersama 22 unit sepeda motor dan berbagai senjata tajam, seperti samurai lima unit, celurit, gir sepeda motor yang diikat, ikat pinggang, kayu dan dua bendera geng. Fenomena-fenomena tersebut menunjukkan remaja seringkali meluapkan kelebihan energinya ke arah negatif. Perilaku emosi berlebihan dan tindakan negatif yang ditampilkan tersebut berkaitan erat dengan kecerdasan emosional (Goleman, 2007). Untuk mengatasi masalah tersebut remaja dituntut memiliki kecerdasan emosional. Kecerdasan emosional yaitu kecerdasan dalam menjalin interaksi sosial untuk membina hubungan yang baik dan efektif dengan orang lain atau antar individu (Martin, 2003). Remaja yang mempunyai kecerdasan emosional tinggi atau berkarakter akan terhindar dari masalah-masalah umum yang 
dihadapi oleh remaja. Selain itu, remaja yang mempunyai kecerdasan kognitif tinggi tidak menjamin kesuksesannya dalam karir jika tidak dibarengi kecerdasan emosional. Penelitian yang dilakukan oleh Thaib (2013) tentang hubungan antara prestasi belajar dengan kecerdasan emosional didapatkan bahwa kecerdasan emosional merupakan salah satu faktor yang penting yang harus dimiliki oleh siswa untuk meraih prestasi belajar yang lebih baik disekolah serta menyiapkan mereka menghadapi dunia nyata. Hal ini sesuai dengan pendapat Goleman (2006) tentang keberhasilan seseorang di masyarakat, $80 \%$ dipengaruhi oleh kecerdasan emosional dan hanya $20 \%$ ditentukan oleh kecerdasan otak (IQ).

Remaja dengan kecerdasan emosional yang baik juga akan terhindar dari sikap dan perilaku menyimpang dan mampu menyeimbangkan antara perasaan dan pikirannya. Hal ini sesuai dengan penelitian yang dilakukan oleh Latifah (2010) tentang hubungan antara kecerdasan emosional dengan akhlak siswa kelas XI SMA Triguna Utama Tangerang Selatan didapatkan adanya hubungan yang cukup signifikan antara kecerdasan emosional dengan akhlak siswa kelas XI SMA Triguna Utama Tangerang Selatan. Seseorang yang memiliki kecerdasan emosional yang tinggi akan mampu mengenali perasaannya sendiri dan perasaan orang lain sehingga mampu memotivasi dirinya sendiri serta mampu mengelola emosinya secara baik dalam hubungannya dengan orang lain. Kecerdasan emosi memiliki peran penting dalam perkembangan manusia, dengan memiliki kecerdasan emosi yang tinggi manusia dapat mengendalikan emosinya termasuk juga kemampuan seseorang untuk mengendalikan perasaannya sendiri sehingga tidak meledak dan akhirnya dapat mempengaruhi perilakunya (Goleman, 2000).

Upaya mengembangkan emosi remaja agar berkembang ke arah kecerdasan emosional dapat dilakukan dengan memberikan pemahaman tentang kecerdasan emosional yang baik pada remaja melalui pendidikan kesehatan, layanan konseling serta pelatihan emosi (Safaria, 2009). Menurut Goleman (2007) untuk mengembangkan emosi remaja menjadi cerdas dapat dilakukan dengan memberikan intervensi pendidikan yang memuat materi tentang Self Science Curriculum yaitu belajar mengembangkan kesadaran diri, mengambil keputusan pribadi, mengelola perasaan, menangani stres, belajar berempati, belajar berkomunikasi, membuka diri, mengembangkan pemahaman, menerima diri sendiri, mengembangkan tanggungjawab pribadi, mengembangkan ketegasan, mempelajari dinamika kelompok dan belajar menyelesaikan konflik (Ali \& Asrori, 2017).

SMK N 5 Padang merupakan sekolah menengah kejuruan yang menghasilkan lulusan siap bersaing dalam dunia kerja. Adapun visi dari SMK N 5 Padang yaitu cerdas, kompetitif dan berbudi luhur. Untuk mencapai visi tersebut, salah satu misi yang dijalankan SMK N 5 Padang adalah mewujudkan pendidikan yang menghasilkan lulusan cerdas intelektual, emosional dan spiritual. Berdasarkan data dari Satpol PP Kota Padang, dari 41 SMK di Kota Padang, SMK N 5 Padang merupakan sekolah yang paling rawan terhadap perilaku tawuran disepanjang tahun 2016. Jumlah seluruh siswa SMK N 5 Padang berjumlah 1300.000. Laporan kasus bagian kesiswaan SMK N 5 Padang dari bulan September sampai dengan November 2017 tercatat, kasus yang paling menonjol adalah keterlambatan, berada diluar lingkungan sekolah saat jam pelajaran, merokok, berkata kotor, membawa handphone yang berisi foto-foto porno, membawa senjata tajam ke sekolah dan tawuran. Hasil studi pendahuluan yang dilakukan peneliti di SMK N 5 Padang pada tanggal 30 November 2017 terhadap 12 siswa, $66,67 \%$ siswa mengatakan bahwa sering tidak bisa mengontrol emosinya dan cenderung melakukan hal-hal yang negatif seperti sering tidak masuk sekolah dan sering ikut dalam aksi tawuran antar sekolah. Mereka mengatakan bahwa mereka tidak bisa mengendalikan dorongan untuk menyerang orang lain ketika dipancing emosinya. Dari hasil pengamatan peneliti pada saat jam pelajaran banyak siswa menghabiskan waktunya dudukduduk di warung pinggir jalan. Pihak sekolah sudah mengupayakan pemberian sanksi kepada siswa dengan pemberian skoring, pemanggilan orang tua serta sanksi berupa hafalan ayat, namun hal tersebut tidak memberikan pengaruh yang besar terhadap perubahan perilaku siswa. Hal ini menandakan masih rendahnya kecerdasan emosional yang dimiliki oleh siswa.

\section{METODA PENELITIAN}

Jenis penelitian yang digunakan dalam penelitian ini adalah penelitian kuantitatif. Desain penelitian adalah quasy experimental dengan rancangan pre test-post test control group design. Sampel terdiri dari 42 responden yang terdiri dari: siswa Kelas XI SMK N 5 Padang, berada ditempat sewaktu dilakukan pengumpulan data, bersedia menjadi responden. Instrumen yang digunakan berupa kuesioner. Analisis data terdiri dari univariat dan bivariat. 


\section{HASIL PENELITIAN}

Penelitian ini dilaksanakan di SMK N 5 Padang. SMK N 5 Padang terletak di jl. S.Parman tepatnya di jl. Beringin no 4 Lolong Padang Kecamatan Padang Utara.

\section{A. Hasil Analisa Univariat}

3.1 Distribusi Karakteristik Responden Berdasarkan Umur, Jenis Kelamin dan Tinggal Bersama Orang tua di SMK N 5 Padang $(n=42)$

\begin{tabular}{lcccc}
\hline \multirow{2}{*}{ Karakteristik } & \multicolumn{2}{c}{$\begin{array}{c}\text { Kelompok } \\
\text { Kontrol }\end{array}$} & \multicolumn{2}{c}{$\begin{array}{c}\text { Kelompok } \\
\text { Intervensi }\end{array}$} \\
\cline { 2 - 5 } & $\mathbf{n}$ & $\mathbf{( \% )}$ & $\mathbf{n}$ & $\mathbf{( \% )}$ \\
\hline Umur & & & & \\
16 & 9 & 42,9 & 7 & 33,3 \\
17 & 12 & 57,1 & 14 & 66,7 \\
\hline Jenis Kelamin & & & & \\
$\quad$ Laki-laki & 18 & 85,7 & 16 & 76,2 \\
$\quad$ Perempuan & 3 & 14,3 & 5 & 23,8 \\
\hline Tinggal Bersama & & & & \\
Orang tua & & & & \\
$\quad$ Ya & 16 & 76,2 & 18 & 85,7 \\
$\quad$ Tidak & 5 & 23,8 & 3 & 14,3 \\
\hline
\end{tabular}

Berdasarkan tabel 3.1 dapat dilihat bahwa karakteristik responden berdasarkan umur pada kedua kelompok sebagian besar berada pada umur 17 tahun. Pada kelompok kontrol responden berumur 17 tahun berjumlah 12 responden $(57,1 \%)$ sedangkan pada kelompok intervensi responden berumur 17 berjumlah 14 responden $(66,7 \%)$.

3.2 Distribusi Pre test Kecerdasan Emosional Siswa pada Kelompok Kontrol

\begin{tabular}{lcccc}
\hline & Mean & SD & $\begin{array}{c}\text { Min - } \\
\text { Mak }\end{array}$ & 95\% CI \\
\hline $\begin{array}{l}\text { Pre } \\
\text { test }\end{array}$ & 144,48 & 9,988 & $128-164$ & $139,93-149,02$ \\
\hline
\end{tabular}

Hasil analisis didapatkan rerata pre test kecerdasan emosional siswa adalah 144,48 (95\%: 139,93-149,02), 1 median 142,00 dengan standar deviasi 9,988. Kecerdasan emosional terendah 128 dan kecerdasan emosional tertinggi 164. Hasil estimasi interval dapat dikemukakan bahwa 95\% diyakini bahwa rerata pre test kecerdasan emosional kelompok kontrol adalah diantara 139,93 sampai dengan 149,02.

\subsection{Distribusi Post Test Kecerdasan Emosional Siswa pada Kelompok Kontrol}

\begin{tabular}{lcccc}
\hline Variabel & Mean & Med & $\begin{array}{c}\text { Min - } \\
\text { Mak }\end{array}$ & 95\% CI \\
\hline Post test & 142,95 & 141,00 & $131-170$ & $\begin{array}{c}138,45- \\
147,46\end{array}$ \\
& & & & \\
\hline
\end{tabular}

Hasil analisis didapatkan rerata post test kecerdasan emosional siswa adalah 142,95 (95\%: 138,45-147,46), median 141,00 dengan standar deviasi 9,892. Kecerdasan emosional terendah 131 dan kecerdasan emosional tertinggi 170. Hasil estimasi interval dapat dikemukakan bahwa 95\% diyakini bahwa rerata post test kecerdasan emosional kelompok kontrol adalah diantara 138,45 sampai dengan 147,46.

\section{B. Hasil Analisa Univariat}

3.4 Distribusi Rerata Kecerdasan Emosional pada Kelompok Kontrol Siswa Di SMK N 5 Padang

\begin{tabular}{cccccc}
\hline & Mean & SD & SE & p Value & N \\
\cline { 1 - 4 } $\begin{array}{c}\text { Pre } \\
\text { test }\end{array}$ & 144,48 & 9,988 & 2,180 & 0,450 & 21 \\
\cline { 1 - 3 } $\begin{array}{c}\text { Post } \\
\text { test }\end{array}$ & 142,95 & 9,892 & 2,159 & & \\
\hline
\end{tabular}

Rerata kecerdasan emosional kelompok kontrol pada pre test adalah 144,48 dengan standar deviasi 9,988. Pada post test rerata kecerdasan emosional 142,95 dengan standar deviasi 9,892. Terlihat perbedaan rerata kecerdasan emosional antara pre test dan post test 1,524 dengan standar deviasi 9,064. Hasil uji statistik didapatkan nilai 0,450 maka dapat dikemukakan tidak ada perbedaan yang signifikan antara pre test dan post test pada kelompok kontrol.

3.5 Distribusi Rerata Kecerdasan Emosional pada Kelompok Kontrol Berdasarkan 5 Aspek Kecerdasan Emosional

\begin{tabular}{lllcccc}
$\mathbf{N}$ & $\begin{array}{c}\text { Varia } \\
\text { bel }\end{array}$ & Mean & Med & SD & $\begin{array}{c}\text { Min- } \\
\text { Mak }\end{array}$ & $\begin{array}{c}\text { 95\% } \\
\text { CI }\end{array}$ \\
\hline 1 & \multicolumn{7}{l}{$\begin{array}{l}\text { Mengenali diri sendiri } \\
\text { (Self-Awarness) }\end{array}$} \\
\hline & Pre & 28,05 & 28,00 & 1,857 & $23-31$ & $27,20-$ \\
& Test & & & & & 28,89 \\
\hline & Post & 27,57 & 27,00 & 1,720 & $25-32$ & $26,79-$ \\
& Test & & & & & 28,35
\end{tabular}

2 Mengelola emosi (Self-Control) 
Volume 2 Nomor 2 P-ISSN : 2597-8594

\begin{tabular}{|c|c|c|c|c|c|c|}
\hline & $\begin{array}{l}\text { Pre } \\
\text { Test }\end{array}$ & 28,81 & 28,00 & 2,962 & $25-35$ & $\begin{array}{c}27,48- \\
30,14\end{array}$ \\
\hline & $\begin{array}{l}\text { Post } \\
\text { Test }\end{array}$ & 29,81 & 30,00 & 2,943 & $25-36$ & $\begin{array}{c}28,47- \\
31,15\end{array}$ \\
\hline 3 & \multicolumn{6}{|c|}{ Memotivasi diri sendiri (Self-Motivation) } \\
\hline & $\begin{array}{l}\text { Pre } \\
\text { Test }\end{array}$ & 33,86 & 33,00 & 2,937 & $28-39$ & $\begin{array}{c}32,52- \\
35,19\end{array}$ \\
\hline & $\begin{array}{l}\text { Post } \\
\text { Test }\end{array}$ & 33,71 & 33,00 & 2,777 & $29-40$ & $\begin{array}{l}32,45- \\
34,98\end{array}$ \\
\hline 4 & \multicolumn{6}{|c|}{ Mengenali emosi orang lain (Emphaty) } \\
\hline & $\begin{array}{l}\text { Pre } \\
\text { Test }\end{array}$ & 23,00 & 23,00 & 2,387 & $19-28$ & $\begin{array}{c}21,91- \\
24,09\end{array}$ \\
\hline & $\begin{array}{l}\text { Post } \\
\text { Test }\end{array}$ & 22,14 & 22,00 & 2,220 & $18-26$ & $\begin{array}{c}21-13- \\
23,15\end{array}$ \\
\hline 5 & \multicolumn{6}{|c|}{ Membina hubungan dengan orang lain (Social-Skill) } \\
\hline & $\begin{array}{l}\text { Pre } \\
\text { Test }\end{array}$ & 30,86 & 30,00 & 4,638 & $22-39$ & $\begin{array}{c}28,73- \\
32,99\end{array}$ \\
\hline & $\begin{array}{l}\text { Post } \\
\text { Test }\end{array}$ & 29,71 & 22,00 & 2,220 & $18-26$ & $\begin{array}{c}21-13- \\
23,15\end{array}$ \\
\hline
\end{tabular}

Hasil analisis didapatkan rerata siswa mengenali diri sendiri adalah pre test 28,05 (95\%: 27,20-28,89), median 27.00 dengan standar deviasi 1,857. Mengenali diri sendiri terendah 23 dan tertinggi 31. Dari hasil estimasi interval dapat disimpulkan bahwa 95\% diyakini bahwa rerata mengenali diri sendiri diantara 27,20 sampai dengan 28,89. Hasil analisis didapatkan rerata siswa mengenali diri sendiri adalah post test 27,57 (95\%: 26,79 28,35), median 27.00 dengan standar deviasi 1,720. Mengenali diri sendiri terendah 25 dan tertinggi 32. Dari hasil estimasi interval dapat disimpulkan bahwa $95 \%$ diyakini bahwa rerata mengenali diri sendiri diantara 26,79 sampai dengan 28,35.

\subsection{Distribusi Rerata Kecerdasan Emosional pada Kelompok Intervensi Siswa di SMK N 5 Padang}

\begin{tabular}{cccccc}
\hline & Mean & SD & SE & $\begin{array}{c}\mathrm{p} \\
\text { Value }\end{array}$ & $\mathrm{N}$ \\
\cline { 1 - 4 } Pre test & 145,38 & 8,611 & 1,879 & 0,002 & 21 \\
\cline { 1 - 5 } Post test & 151,38 & 8,692 & 1,897 & & \\
\hline
\end{tabular}

Rerata kecerdasan emosional kelompok intervensi pada pre test adalah 145,38 dengan standar deviasi 8,611. Pada post test rerata kecerdasan emosional 151,38 dengan standar deviasi 8,692. Terlihat perbedaan rerata kecerdasan emosional antara pre test dan post test 6,000 dengan standar deviasi 7,537. Hasil uji statistik didapatkan nilai 0,002 maka dapat dikemukakan ada perbedaan yang signifikan antara pre test dan post test pada kelompok intervensi.

3.7 Distribusi Rerata Kecerdasan Emosional pada Kelompok Intervensi Berdasarkan 5 Aspek Kecerdasan Emosional

\begin{tabular}{|c|c|c|c|c|c|c|}
\hline $\begin{array}{l}\mathbf{N} \\
\mathbf{o}\end{array}$ & $\begin{array}{c}\text { Variabe } \\
l\end{array}$ & $\begin{array}{c}\text { Mea } \\
\text { n }\end{array}$ & $\begin{array}{c}\text { Media } \\
\mathbf{n}\end{array}$ & SD & $\begin{array}{c}\text { Min } \\
- \\
\text { Mak } \\
\end{array}$ & $\begin{array}{c}95 \% \\
\text { CI }\end{array}$ \\
\hline 1 & \multicolumn{6}{|c|}{ Mengenali diri sendiri (Self-Awarness) } \\
\hline & Pre Test & 29,05 & 30,00 & $\begin{array}{c}2,29 \\
1\end{array}$ & $\begin{array}{l}25- \\
32\end{array}$ & $\begin{array}{c}28,00 \\
- \\
30,09\end{array}$ \\
\hline & $\begin{array}{l}\text { Post } \\
\text { Test }\end{array}$ & 29,43 & 30,00 & $\begin{array}{c}2,87 \\
4\end{array}$ & $\begin{array}{l}23- \\
33\end{array}$ & $\begin{array}{c}28,12 \\
- \\
30,74\end{array}$ \\
\hline 2 & \multicolumn{6}{|c|}{ Mengelola emosi (Self-Control) } \\
\hline & Pre Test & 28,95 & 29,00 & $\begin{array}{c}3,07 \\
4\end{array}$ & $\begin{array}{l}23- \\
33\end{array}$ & $\begin{array}{c}27,55 \\
- \\
30,35\end{array}$ \\
\hline & $\begin{array}{l}\text { Post } \\
\text { Test }\end{array}$ & 31,71 & 32,00 & $\begin{array}{c}2,41 \\
1\end{array}$ & $\begin{array}{l}27- \\
35\end{array}$ & $\begin{array}{c}30,62 \\
- \\
32,81 \\
\end{array}$ \\
\hline 3 & \multicolumn{6}{|c|}{ Memotivasi diri sendiri (Self-Motivation) } \\
\hline & Pre Test & 34,14 & 33,00 & $\begin{array}{c}2,85 \\
1\end{array}$ & $\begin{array}{l}30- \\
38\end{array}$ & $\begin{array}{c}32,85 \\
- \\
35,44\end{array}$ \\
\hline & $\begin{array}{l}\text { Post } \\
\text { Test }\end{array}$ & 34,67 & 34,00 & $\begin{array}{c}2,08 \\
2\end{array}$ & $\begin{array}{l}30- \\
38\end{array}$ & $\begin{array}{c}33,72 \\
- \\
35,61\end{array}$ \\
\hline 4 & \multicolumn{6}{|c|}{ Mengenali emosi orang lain (Emphaty) } \\
\hline & Pre Test & 22,67 & 23,00 & $\begin{array}{c}2,59 \\
5\end{array}$ & $\begin{array}{l}17- \\
28\end{array}$ & $\begin{array}{c}21,49 \\
- \\
23,85\end{array}$ \\
\hline & $\begin{array}{l}\text { Post } \\
\text { Test }\end{array}$ & 23,24 & 24,00 & $\begin{array}{c}2,96 \\
5\end{array}$ & $\begin{array}{l}19- \\
28\end{array}$ & $\begin{array}{c}21,89 \\
- \\
23,21 \\
\end{array}$ \\
\hline 5 & \multicolumn{6}{|c|}{$\begin{array}{l}\text { Membina hubungan dengan orang lain (Social- } \\
\text { Skill) }\end{array}$} \\
\hline & Pre Test & 30,57 & 30,00 & $\begin{array}{c}3,94 \\
4\end{array}$ & $\begin{array}{c}23- \\
38\end{array}$ & $\begin{array}{c}28,78 \\
- \\
32,37\end{array}$ \\
\hline & $\begin{array}{l}\text { Post } \\
\text { Test }\end{array}$ & 32,33 & 32,00 & $\begin{array}{c}3,69 \\
2\end{array}$ & $\begin{array}{l}26- \\
39\end{array}$ & $\begin{array}{c}30,65 \\
- \\
34,01\end{array}$ \\
\hline
\end{tabular}

Hasil analisis didapatkan rerata siswa mengenali diri sendiri adalah pre test 29,05 (95\%: 28,00-30,09), median 30.00 dengan standar deviasi 2,291. Mengenali diri sendiri terendah 25 dan tertinggi 32. Dari hasil estimasi interval dapat disimpulkan bahwa 95\% diyakini bahwa rerata mengenali diri sendiri diantara 28,00 sampai dengan 30,09. Hasil analisis didapatkan rerata siswa mengenali diri sendiri adalah post test 29,43 (95\%: 28,1230,74 ), median 30.00 dengan standar deviasi 2,874. Mengenali diri sendiri terendah 23 dan tertinggi 33. Dari hasil estimasi interval dapat disimpulkan bahwa 95\% 
diyakini bahwa rerata mengenali diri sendiri diantara 28,12 sampai dengan 30,74 .

\subsection{Efektivitas Pendidikan Kesehatan terhadap} Kecerdasan Emosional Siswa di SMK N 5 Padang

\begin{tabular}{lllllll} 
& $\begin{array}{l}\text { kelompok } \\
\text { penelitian }\end{array}$ & Mean & SD & SE & p Value & N \\
\hline nilai & $\begin{array}{l}\text { tidak } \\
\text { post } \\
\text { test }\end{array}$ & & & & & \\
& $\begin{array}{l}\text { dilakukan } \\
\text { intervensi } \\
\text { pendidikan } \\
\text { kesehatan }\end{array}$ & 142,95 & 9,892 & 2,159 & & 21 \\
& $\begin{array}{l}\text { dilakukan } \\
\text { intervensi } \\
\text { pendidikan } \\
\text { kesehatan }\end{array}$ & 151,38 & 8,692 & 1,897 & & 21 \\
& & & & & & \\
\end{tabular}

Rerata nilai post test kecerdasan emosional siswa kelompok kontrol adalah 142,95 dengan standar deviasi 9,892, sedangkan post test pada kelompok intervensi adalah 151,38 dengan standar deviasi 8,692. Hasil uji statistik didapatkan nilai $\mathrm{p}=0,006$, berarti pada alpha $5 \%$ terlihat ada perbedaan yang signifikan rerata posttest antara kelompok yang tidak dilakukan intervensi pendidikan kesehatan dengan kelompok yang dilakukan intervensi pendidikan kesehatan.

\section{PEMBAHASAN}

Hasil penelitian pada tabel 3.1 menunjukkan sebagian besar responden $(61,9 \%)$ berusia 17 tahun. Responden pada penelitian ini berada pada fese remaja pertengahan (15-17 tahun) (Perry \& Potter, 2009). Hasil penelitian ini sejalan dengan pendapat Hurlock (1999) dimana pada usia ini, umumnya anak berada dibangku sekolah menengah.

Pada penelitian ini juga didapatkan sebagian besar responden $(81,0 \%)$ tinggal bersama orang tua. Menurut Sarwono (2004) keberadaan anak bersama orang tua secara langsung atau tidak langsung mempengaruhi kemampuan perkembangan emosi anak. Ali \& Asrori (2017) juga mengemukakan bahwa salah satu faktor yang mempengaruhi perkembangan emosi remaja adalah perubahan pola interaksi orang tua yang bervariasi antara lain bersifat otoriter, memanjakan, acuh tak acuh bahkan dengan penuh cinta kasih.

Hal ini sesuai dengan penelitian yang dilakukan oleh Kristiani (2015) tentang hubungan tipe pola asuh orang tua dengan kecerdasan emosional remaja di SMK Muhammadiyah 1 Surakarta menyatakan bahwa ada hubungan antara tipe pola asuh orang tua dengan kecerdasan emosional remaja. Penelitian yang dilakukan oleh Finkenauer dkk (2005) tentang perilaku pengasuhan, perilaku remaja dan masalah emosional juga mengatakan bahwa pengasuhan berhubungan erat dengan perilaku emosi remaja.

Hasil penelitian pada tabel 3.4 menunjukkan perbedaan rerata kecerdasan emosional antara pre test dan pre test 144,48 dan post test 142,95 . Berdasarkan analisis peneliti, terjadinya penurunan rerata post test pada kelompok kontrol dikarenakan memang tidak ada usaha untuk meningkatkan kecerdasan emosional pada kelompok kontrol namun tetap dilakukan pengukuran yang sama dengan kelompok intervensi. Terjadinya penurunan nilai pre test dan post test juga dapat saja terjadi dikarenakan dikarenakan pengetahuan seseorang terhadap objek mempunyai intensitas atau tingkat yang berbeda-beda, hal ini didasarkan pada ingatan (memory) yang berasal dari pengalaman dan kekuatan informasi yang didapat (Notoatmodjo, 2010).

Kecerdasan emosional berdasarkan 5 aspek kecerdasan emosional antara lain :

\section{a. Mengenali diri sendiri (self awareness)}

Hasil penelitian pada kelompok kontrol didapatkan rerata kemampuan mengenali diri sendiri pre test 28,05 dan post test 27,57. Disini terlihat terjadi penurunan rerata kemampuan mengenali diri sendiri pada kelompok kontrol. Menurut analisa peneliti, penurunan rerata tersebut dikarenakan ketidaktahuan responden dalam meningkatkan self awareness. Perawat dalam fungsinya sebagai edukator sangat berperan dalam memberikan pendidikan kesehatan kepada remaja dan memberikan keterampilan dasar tentang meningkatkan kesadaran diri. Sejumlah ahli mengemukakan bahwa dengan meningkatkan keterampilan dasar tersebut pada remaja diharapkan remaja mampu mengembangkan potensi yang dimiliki serta berani menghadapi masalah kehidupan serta memecahkannya secara kreatif. Hal ini diperkuat oleh peneltian yang dilakukan oleh Ciarrochi (2001) tentang mengukur kecerdasan emosional pada remaja, menyatakan bahwa pendidikan kesehatan dapat diberikan kepada remaja untuk membantu meningkatkan kecerdasan emosional remaja.

Self awareness atau kesadaran diri adalah wawasan mengenai alasan-alasan dari tingkah laku sendiri atau pemahaman diri sendiri. Self awareness merupakan bahan baku yang penting untuk menunjukkan kejelasan dan pemahaman tentang perilaku seseorang. Kesadaran diri juga merupakan suatu yang bisa memungkinkan orang lain mampu mengamati dirinya sendiri maupun 
membedakan dirinya dari dunia (orang lain), serta memungkinkan orang lain mampu menempatkan diri dari suatu waktu dan keadaan. Kesadaran diri memang belum menjamin penguasaan emosi, namun merupakan salah satu prasyarat penting untuk mengendalikan emosi sehingga individu mudah menguasai emosi, memahami penyebab dari perasaan yang timbul dan mengenal pengaruh perasaan terhadap tindakan.

Menurut Goleman (2007) dalam kesadaran diri ada 3 kecakapan yang perlu dikuasai yaitu mengenali emosi diri dan pengaruhnya, pengakuan diri yang akurat; mengetahui sumber daya batiniah (kemampuan dan keterbatasan) serta kepercayaan diri. Untuk membentuk self awareness dalam diri seseorang dibutuhkan sebuah kerangka kerja yang terdiri dari 5 elemen yaitu 1) attention (perhatian), 2) wakefulness (kesadaran), 3) architecture (proses yang menyokong kesadaran), 4) recall of knowledge (proses pengambilan informasi dengan dunia sekeliling), 5) self knowledge (pengetahuan diri) (Solso, 2008).

b. Mengelola emosi (self control)

Hasil penelitian tentang mengelola emosi (self control) pada kelompok kontrol mengalami peningkatan rerata. Berdasarkan setiap item pertanyaan peningkatan terlihat pada item pertanyaan no 8, 9, 1011,12 dan 15 . Namun pada item pertanyaan no 13, dan 14 terjadi penurunan. Menurut analisa peneliti, terjadinya penurunan tersebut dikarenakan masa remaja merupakan masa "kritis dan badai". Adanya perubahan fisik yang tidak diikuti dengan perkembangan emosi menyebabkan remaja mudah terjerumus ke perilaku negatif. Secara biologis perkembangan otak remaja belum berkembang sempurna, yang berakibat pada psikologis emosional remaja, yang kadang bersikap seperti anak-anak dan kadang bersikap dewasa. Remaja belum mempunyai kemampuan dalam membaca dan memahami emosi dari dalam dirinya ataupun orang lain. Perubahan biologis remaja berpengaruh pada kontrol diri, penilaian, emosi, dan pengaturan diri.

Mengelola emosi merupakan kemampuan individu dalam menangani perasaan agar dapat terungkap dengan tepat atau selaras sehingga tercapai keseimbangan dalam diri individu. Menjaga agar emosi yang merisaukan tetap terkendali merupakan kunci menuju kesejahteraan emosi. Emosi berlebihan yang meningkat dengan intensitas terlampau lama akan mengoyak kestabilan kita. Kemampuan ini mencakup kemampuan untuk menghibur diri sendiri, melepaskan kecemasan, kemurungan atau ketersinggungan dan akibat-akibat yang ditimbulkannya serta kemampuan untuk bangkit dari perasaan-perasaan yang menekan(Goleman, 2007).

Seseorang dikatakan mempunyai keterampilan mengelola emosi jika memiliki kemampuan mengendalikan diri (sabar), dapat dipercaya, berhati-hati, keluwesan dalam menghadapi perubahan dan tantangan (adaptibilitas), bersikap terbuka terhadap gagasan dan pendekatan-pendekatan baru serta informasi terkini (inovasi).

c. Memotivasi diri sendiri (self motivation)

Hasil penelitian pada kelompok kontrol didapatkan rerata kemampuan memotivasi diri sendiri pre test 33,86 dan post test 33,76. Disini terlihat tidak terjadi peningkatan rerata kemampuan memotivasi diri sendiri pada kelompok kontrol. Menurut analisa peneliti, tidak terjadi peningkatan rerata kemampuan memotivasi diri sendiri dikarenakan tidak adanya arahan pada kelompok kontrol tentang cara meningkatkan kemampuan memotivasi diri (self motivation). Pada masa remaja merupakan masa pencarian identitas diri tentang konsep diri, tujuan hidup, nilai dan keyakinan yang dipegang. Remaja selalu bereksperimen dan berusaha untuk menemukan siapa mereka sebenarnya, apa saja yang ada dalam diri mereka dan arah mereka dalam menjalani hidup.

Berdasarkan teori motivasi, terbentuknya perilaku dimulai dengan tahap sebagai berikut : 1) tahap persepsi (perception). Pada tahap ini orang akan menerima rangsangan dari luar kemudian masuk melalui inderainderanya. Rangsangan itu misalnya dalam bentuk pendidikan kesehatan yang memberikan informasi. 2) Tahap penilaian (apprasial), pada tahap ini rangsangan yang masuk ke dalam otaknya selanjutnya akan dinilai dengan ukuran-ukuran nilai yang ada pada dirinya. 3) Emosi (emotion), apabila hasil penilaian itu cocok atau sejalan dengan nilai dirinya maka akan timbul rasa senang, dan jika tidak sejalan dengan dirinya maka akan timbul perasaan tidak senang. 4) Ekspresi (expresion), pada tahap ini emosi yang muncul akan mendorong seseorang untuk menyatakan ungkapan dirinya. Ungkapan tersebut dapat berupa ekspresi verbal dan non verbal. 5) Tindakan (action), pada tahap ini tindakan akan muncul yang disertai emosi. Persepsi atau pemahaman yang benar mengenai kecerdasan emosional secara positif akan memberi peluang untuk berubah perilakunya dari yang kurang atau belum menjadi positif (Handoko, 2012).

d. Mengenali emosi orang lain (emphaty)

Hasil penelitian pada kelompok kontrol didapatkan rerata kemampuan mengenali emosi orang lain pre test 23,00 dan post test 22,14. Menurut analisa peneliti 
terjadinya penurunan disebabkan kurangnya pemahaman remaja tentang perilaku empati. Hal ini terlihat dari perilaku remaja yang membentuk gang atau kelompok yang tidak saling menghargai dan menghormati sesama, bersikap tidak acuh. Hal ini diperkuat menurut Hastings (2008) yang menyatakan bahwa anak yang memiliki kekurangan empati menunjukkan ketidakpedulian terhadap sesama yang diwujudkan dalam bentuk kemarahan, kekerasan dan menertawakan ketidak beruntungan yang dialami oleh orang lain.

Empathy merupakan kemampuan untuk mengenal, mengerti dan merasakan perasaan orang lain. Penumbuhan perasaan empati diperlukan oleh para remaja. Empati memiliki manfaat agar individu menjadi lebih ramah dan stabil secara emosional. Empati dapat menimbulkan sikap membantu dan pro-sosial. Selain itu empati memiliki manfaat agar individu menjadi lebih ramah dan stabil secara emosional (Assegraf, 2004). Goleman (2007) mengemukakan kemampuan empati yang harus dimiliki dalam kecerdasan emosional adalah mendengarkan bicara orang lain dengan baik, menerima sudut pandang orang lain dan peka terhadap perasaan orang lain. skill)

e. Membina hubungan dengan orang lain (social

Kemampuan dalam membina hubungan merupakan suatu keterampilan yang menunjang popularitas, kepemimpinan, dan keberhasilan antarpribadi. Keterampilan dalam berkomunikasi merupakan kemampuan dasar dalam keberhasilan membina hubungan. Individu sulit untuk mendapatkan apa yang diinginkannya dan sulit juga memahami keinginan serta kemauan orang lain.

Orang-orang yang hebat dalam keterampilan membina hubungan ini akan sukses dalam bidang apapun. Orang berhasil dalam pergaulan karena mampu berkomunikasi dengan lancar pada orang lain. Orangorang ini popular dalam lingkungannya dan menjadi teman yang menyenangkan karena kemampuannya berkomunikasi. Ramah tamah, baik hati, hormat, dan disukai orang lain dapat dijadikan petunjuk positif bagaimana siswa mampu membina hubungan dengan orang lain. Sejauh mana kepribadian siswa berkembang dilihat dari banyaknya hubungan interpersonal yang dilakukannya.

\section{KESIMPULAN}

Karakteristik responden sebagian besar berusia 17 tahun $(61,9 \%), 81,0 \%$ responden berjenis kelamin laki-laki dan tinggal bersama orang tua. Rerata kecerdasan emosional siswa kelompok kontrol pada pre test adalah 144,48 dengan standar deviasi 9,988. Pada post test rerata kecerdasan emosional 142,95 dengan standar deviasi 9,064. Hasil uji statistik tidak ada perbedaan yang signifikan antara kecerdasan emosional sebelum dan setelah pada kelompok kontrol $(\mathrm{p}=0,450)$

Rerata kecerdasan emosional siswa kelompok intervensi pada pre test adalah 145,38 dengan standar deviasi 8,611. Pada post test rerata kecerdasan emosional 151,38 dengan standar deviasi 8,692. Hasil uji statistik ada perbedaan yang signifikan antara kecerdasan emosional sebelum dan setelah intervensi pendidikan kesehatan pada kelompok intervensi $(\mathrm{p}=0,002)$.

Efektivitas pendidikan kesehatan dapat dilihat dari hasil uji statistik antara kelompok kontrol dan kelompok intervensi $(\mathrm{p}=0,006)(\mathrm{p}<0,05)$, disimpulkan ada efektivitas pendidikan kesehatan terhadap kecerdasan emosional siswa di SMK N 5 Padang.

Disarankan bagi pihak sekolah, khususnya bagian kesiswaan SMK N 5 Padang dapat menjadikan pendidikan kesehatan tentang kecerdasan emosional ini ke dalam bagian kegiatan UKS SMK N 5 Padang guna mencapai salah satu misi sekolah yaitu mewujudkan pendidikan yang menghasilkan lulusan cerdas intelektual, emosional dan spiritual. Peneliti selanjutnya disarankan untuk menggunakan metode role play untuk meningkatkan kecerdasan emosional mengingat masa remaja merupakan masa dimana fluktuasi emosi berlangsung lebih sering terutama pada remaja awal.

\section{DAFTAR PUSTAKA}

Ali \& Asrori. 2017. Psikologi Remaja Perkembangan Peserta Didik. Jakarta: PT Bumi Aksara.

Barry et al. 2013. A Systematic Review of The Effectiveness of Mental Health Promotion Interventions fo Young People in Low and Middle Income Countries. BMC Public Health. http://www.biomedcentral.com/1471-

2458/13/835. Diperoleh 17 Februari 2018.

BKKBN. 2016. Jurnal Keluarga Revolusi Mental Membangun Karakter Bangsa dari Ajang Genre 2016. Edisi kedelapan ISSN : 0304-9159.

Catio, Mukhlis. 2013. Peran Pendidikan dalam Mengatasi Masalah Kesehatan Remaja dalam The $2^{\text {nd }}$ Adolescent Health National Symposia: Current Challenges in Management. http://www.idai.or.id/artikel/seputar-kesehatananak/peran-pendidikan-dalam-mengatasimasalah-kesehatan-remaja. Diperoleh 8 Oktober 2017. 
Di Sumbar, Masalah Kenakalan Remaja dan Narkoba Sangat Tinggi oleh Kincai (2016, http://www.portalberitaeditor.com/di-sumbarmasalah-kenakalan-remaja-dan-narkoba-sangattinggi/. Diperoleh 5 Oktober 2017).

Fitriani., Sinta. 2011. Promosi Kesehatan. Yogyakarta : Graha Ilmu.

Goleman, Daniel. 2007. Emotional Intelligence (terjemahan). Jakarta: PT.Gramedia Pustaka Utama.

Gunarsa, SD. 2009. Psikologi Perkembangan Anak dan Remaja. Jakarta : PT BPK Gunung Mulia.

Hastono, S. P. 2007. Analisis Data Statistik. Depok : FKM Universitas Indonesia.

Hendak Tawuran di By Pass, Puluhan Remaja Diamankan oleh Caniago (2017. http://hariansinggalang.co.id/hendak-tawuran-diby-pass-puluhan-remaja-diamankan/. Diperoleh 5 Oktober 2017).

Junairi, Asep. 2017. Hubungan Kecerdasan Emosional dengan Prestasi Belajar Sejarah Siswa Kelas XI IPS Di SMA $N 1$ Jati Agung Lampung Selatan TA 2016/2017. Skripsi. Fakultas Keguruan dan Ilmu Pendidikan Universitas Lampung.

Kristiani, Yunita. 2015. Hubungan Tipe Pola Asuh Orangtua dengan Kecerdasan Emosional Remaja Di SMK Muhammadiyah 1 Surakarta. Skripsi. Fakultas Kedokteran Prog.D IV Bidan Pendidik (https://digilib.uns.ac.id/dokumen/detail/47979/H ubungan-Tipe-Pola-Asuh-Orang-Tua-denganKecerdasan-Emosional-Remaja-di-SMKMuhammadiyah-1-Surakarta). Diperoleh 12 Maret 2018.

Latifah, Evilailatul. 2010.Hubungan antara Kecerdasan Emosional dengan Akhlak Siswa Kelas XI SMA Triguna UtamaTangerang Selatan.Skripsi. Fakultas Ilmu tarbiyah dan Keguruan Universitas Islam Negeri Jakarta.

Lembaga Demografi FEB UI. 2017. Ringkasan Studi : Prioritaskan Kesehatan Reproduksi Remaja untuk Menikmati Bonus Demografi. Universitas Indonesia.

Notoatmodjo, Suekidjo. 2012. Promosi Kesehatan dan Perilaku Kesehatan. Jakarta: PT Rineka Cipta.

Nursalam. 2008. Konsep dan Penerapan Metodologi Penelitian Ilmu Keperawatan. Jakarta: Salemba Medika.

Pusat Data dan Informasi Kementerian Kesehatan. 2014. Situasi Kesehatan Reproduksi Remaja. Kementerian Kesehatan RI. ISSN 2442 - 7659.
Pratiwi, Rini Yudhi. 2013. Kesehatan Remaja di Indonesia Buku The ${ }^{2 n d}$ Adolescent Health National Symposia: Current Challenges in Management. http://www.idai.or.id/artikel/seputar-kesehatananak/kesehatan-remaja-di-indonesia. Diperoleh 14 Februari 2018.

Safaria, T. 2009. Manajemen Emosi : Sebuah Panduan Cerdas Bagaimana Mengelola Emosi Positif dalam Hidup Anda. Jakarta : Bumi Aksara.

Santrock, J. W. 2007. Adolescence Perkembangan. Jakarta: Erlangga.

Sari, Indah Prasetyawati Tri Purnama. 2013. Pendidikan Kesehatan Sekolah Sebagai Proses PerubahanPerilaku Siswa. Jurnal Pendidikan Jasmani Indonesia Volume 9 Nomor 2, November 2013.

Susilo. R. 2011. Pendidikan Kesehatan dalam Keperawatan. Yogyakarta : Muha Medika.

Thaib, Eva Nauli. 2013. Hubungan antara Prestasi Belajar denganKecerdasan emosional. Jurnal Ilmiah DIKDAKTIKA Februari. Vol XIII, No 2. 